Vol. 3: (June) 2013

\title{
Revisiting the Life and Thought of Dr. Burhanuddin al-Helmy
}

\author{
SUZY AZIZIYANA SAILI* \& KHAIRULNIZAM MAT KARIM ${ }^{1}$
}

\begin{abstract}
Burhanuddin al-Helmy is the least known name in Malaysian history. However, his role and thought cannot simply be dismissed although some of it were considered as controversial, and him be labelled as radical Malay leader. But one has to browse through his life and thought in order to determine his nature of being. Dr. Burhanuddin is a man of his time, experiencing the downside of British colonization and Japanese occupation. His personal experience in India and Palestine had shaped his conviction that Malaya and the Malay world need to be independent from the British rule. An active man in politics seen especially in his involvement in PKMM (Parti Kebangsaan Melayu Malaya) and Parti Islam seTanah Melayu (PAS), but what is more important is his three most prevalent ideology. He stressed on Malay nationalism; he envision it as a nationalism for independence, humanity and well being; the idea of Greater Malaya; a unification with Indonesia in which he sees it as a political unification for all Malays in the Malay world, and; the influence of Malay rulers; which he is kind of sceptic towards the Malay sultan whom he viewed as jeopardizing the interests of the people.
\end{abstract}

\section{Keywords: Burhanuddin al-Helmy, Malaysian politics, PAS, PKMM}

History had recorded many famous people struggling to achieve the independent of Malaya. Among them, the name Burhanuddin al-Helmy was the least known. Therefore, the objectives of this paper is to revisit the life and thought of this charismatic man as not many references were attributed to him, especially the ideology that he has faith in. What most books highlighted is his participation in the political arena. Even in the political arena, people knew more about Dato' Onn Ja'far although both of them belonged to the same time. The difference is that Dato' Onn belonged to the right wing (UMNO) while Dr. Burhanuddin is said to have belonged to the left wing or the anti-establishment. Dr. Burhanuddin was probably among the early Malays who managed to attain his doctorate at times when his country was still colonized. He strongly advocates that Malaya and the Malay World should be independent from foreign encroachment. He experienced many ups and downs in the political field but he stand firmly with his own conviction. His leadership was particularly clear during his participation in Persatuan Kebangsaan Melayu Malaya (PKMM) and Parti Islam seTanah Melayu (PAS). One thing that is clear, he was more of a nationalist than a reformist although the essence of his struggle was to reform the Malay's societies based in the mould of Islam, and especially using Tasawwuf.

\section{His Life}

Dr. Burhanuddin al-Helmy was born on 29 August 1911 in Cangkat Tualang, Perak, and died on 25 October 1969. His father is Haji Muhammad Nor who was well known by his friends as Melayu Jati (true Malays) and had studied under several famous Makkan scholars during his time (Saliha 1997). The name al-Helmy was derived from the recognition of people towards his father's personality by calling him Abi Halim. In his struggle and idealism, he tried to adapt to

\footnotetext{
${ }^{1}$ Suzy Aziziyana Saili*(Corresponding author), Lecturer at College of Foundation \& General Studies, Universiti Tenaga Nasional, 26700 MUADZAM SHAH, Pahang, Malaysia, Email: suzy@uniten.edu.my; Khairulnizam Mat Karim, Senior Lecturer at College of Foundation \& General Studies, Universiti Tenaga Nasional, 26700 MUADZAM SHAH, Pahang, Malaysia, Email: khairulnizam@uniten.edu.my.
} 
what he called as the Malay Personality (Keperibadian Melayu) which was prevalent in his attitude towards the foreigners. From his early childhood, Dr. Burhanuddin received his first education of al-Qur'an from his own father whom is belonging to the Naqshabandiyya Tariqat. Later on, he was sent to Sumatra to further his education but changed to another school in Padang Serai, Kedah, and finally to Madrasah al-Masyhor in Pulau Pinang. It was in this school that he was influenced by the Middle Eastern magazine; mainly al-Manar which had eventually gives him the progressive interpretation of Islam (Ramlah 1999).

In 1928, he went to India to travel, as well as to further his education. Among his personal experience was observing the movement of Mahatma Gandhi, and meeting famous individuals such as Muhammad Ali Jinnah, Pandit Jawharlal Nehru, and other notable Indian leaders (Kamarudin 1980). Dr. Burhanuddin furthered his studies on homeopathy and was awarded a degree of homeopathy by Ismaeliah Medical College, New Delhi. Later on, he pursued his other degree of Philosophy in Aligarh Muslim University (Kamarudin 1980). It was in India that he was exposed to the struggle of the Indian from the British rule, and also witnessing the tensions between Hindus and Muslims (Ramlah 1999). This experience had ignited the idea of liberating Malaya from the British and was deeply entrenched in his heart. Apart from that, his conviction became even stronger when he witnessed the British policy in Palestine in which he was a volunteer aide to the Palestinian refugee driven out from their homeland (Ramlah 1999).

Upon his return in 1935, Dr. Burhanuddin taught Arabic language in al-Juned Arabic School in Singapore. He was also active in the Islamic movement in the island (Kamarudin 1980). In 1937, he published a magazine known as Taman Bahagia. One of his articles highlighted the misery of the Palestinian refugee as a result of British imperialism. After only one hour of its circulation, the British had him arrested, accusing him of threatening their importance in Malaya (Kamarudin 1980). After that incident, he opened a homeopathy clinic, having its branch in both Singapore and Johor. His involvement in political career started after 1939 when he came into contact with few important figures behind the Kesatuan Melayu Muda (Young Malays).

Mustapha Hussain, one of its leaders, introduced him to KMM but was not active in the movement when the British arrested few of its leaders (Kamarudin 1980). In 1940, the British arrested several prominent KMM leaders such as Ibrahim Yaacob, Ishak Hj. Muhammad, Ahmad Boestamam, and Sutan Djenain (Kamarudin 1980). His involvement in KMM was interrupted with the coming of the Second World War and the Japanese occupation. During the Japanese occupation, Dr. Burhanuddin was appointed as the Advisor of Cultural and Religious Affairs (Saliha 1997). He was using his position to protect and assist the anti-colonial movement, and promoting the sense of solidarity and Malay nationalism. With the Japanese support, he organized a congress of Muslim leadership, particularly in Malaya and Sumatra (Saliha 1997). This congress had stimulated the formation of Islamic movement at national level that was flourishing during the post war period.

His real contribution can be seen after the Japanese surrendered and the British reoccupy Malaya. It was during this time that he joined PKMM (Parti Kebangsaan Melayu Malaya), labelled as the left wing. He dreams of a union between Malaya and Indonesia to be either Greater Malaya or Indonesia (Kamarudin 1980). Though he cooperates with people who were influenced by Communism, he never became one. His faith and stand in Islam was very strong and this is expressed by the title al-Helmy.

\section{His Political Involvement}

Dr. Burhanuddin is a unique political leader in his time. He was the only figure who never formed any political party or to led it. Instead, he was invited to lead the famous political parties such as Parti Kebangsaan Melayu Malaya (PKMM) and Parti Islam seTanah Melayu (PAS) (Ramlah 1993). His importance in politics was clear following his efforts in PKMM which was formed on October 17, 1945 (Ramlah 1993). This party was sponsored by Parti Komunis Malaya (Malayan Communist Party) and became its agent to spread the communist influence among the 
Malays. The agent of PKM such as Mukhtaruddin Lasso, Arshad Ashaari, and a few more, had joined Suara Rakyat, a newspaper that has only been published for a few days by supplying fund and managing its distribution (Ramlah 1993). In the early stage of PKMM formation, Mukhtaruddin Lasso was its first president. After he suddenly disappears, Dr. Burhanuddin took the responsibility to manage PKMM. His involvement in PKMM was considered as crucial in the context of Malay political movement around the year 1946 to 1948. This is because; there exist three important elements that challenged his leadership in Malay's politics. These elements were interconnected and became his platform for his further political activities. The three elements was the main resolution achieved during the congress of PKMM in Perak (1945), Kuala Lumpur (1946), and Malacca (1947) (Ramlah 1993). The resolutions are: Malaya as part of Indonesia: Sang Saka Merah Putih (Indonesian flag) to be adopt as the future national flag; Literally approved to the formation of union for Malaya, and; Cooperation with other races for the benefit of all.

Few important figures in PKMM were not happy with the moderate actions undertaken by him. This includes his close friend, Ahmad Boestamam, and PKMM vice president, Ishak Hj. Mohammad (Ramlah 1993). These people challenged his leadership and one clear example was the withdrawal of PKMM from the union with UMNO on June 1946, during the Annual General Meeting in Ipoh. He did not participate in this meeting and instead, sent three of his representative. This also shows the weakness behind his moderate attitude. He could punish them but take a stand to cover that shameful act of his friends saying that they refused to be the tools of colonizer, just as UMNO is. The excuse made by Ahmad Boestamam along with two other representatives was not convincing enough. Just because of the rejections towards their proposal to use different flag, they had ultimately pulled the rest of PKMM from having union with UMNO. His struggle in PKMM continued only until June 1948 for in the following month, his role as the radical Malay leader was ended when British passed the act of insurgency (Ramlah 1999). However, this is not the end of his political career.

Dr. Burhanuddin was also involved in the formation of a new party, Parti Rakyat Malaya (PRM) but did not participate actively in its activities. PRM was entrusted to Ahmad Boestamam with Dr. Burhanuddin as the party's advisor (Saliha 1997). Even when he didn't join the membership of PRM, people still consult him in the matter of party's decisions. One explanation of his refusal to join any political party at that time was probably because none of it was in line with his aspiration, struggle of independence with Islam as its platform. Parti Islam seTanah Melayu (PAS) during that time was still a conservative religious movement, whereby he on the other side was seen as belonging to the leftist. PAS was the second biggest political party after UMNO. Because of their defeat in the first national election of 1955, those on top of the party decided to invite Dr.Burhanuddin to join it (Saliha 1997).

His involvement in PAS at this stage received different reaction from the observer and other politicians, especially in the matter of his directions, motives, and political aim. Some viewed this positively while others see him as an opportunist, benefiting from the role of Ulama and other religious figure of PAS. Another group regretted his decision to joined PAS, claiming this as only to waste his leadership in a political movement that has no future (Saliha 1997). However, the encouraging development had silenced all those accusation pointed towards him. He was well known to the leader of Afro-Asian countries, and this proved to bring good impact to PAS. Throughout his involvement in politics, he managed to become the Members of Parliament in the House of Representatives using the ticket of PAS. It was clear to him that tugas kebangsaan adalah lebih penting dari tugas kepartian (the national duties are more important than of the party). Sadly, his motion to the parliament such as rupa bangsa atau kerakyatan Persekutuan Tanah Melayu ini dikenali sebagai Melayu (all citizens and those who received the citizenship of Federated Malaya should be known as Malays) and Persekutuan Tanah Melayu dipunyai oleh bangsa Melayu dirakamkan dalam Perlembagaan Persekutuan (Federal Constitution should record that Federated Malaya was owned by the Malays) was never accepted by PAS and other parties (Saliha 1997). Some even viewed his proposal as a kind of racism. Dr. Burhanuddin second the motion of the formation of Malaysia, consisting of Malaya, 
Singapore, Brunei, Sabah, and Sarawak, saying that this is based on the concept of Greater Malaya. However, he wanted to expand the membership to include Indonesia and Philippine but was not successful (Saliha 1997).

His sad experience in political arena and the disappointment towards the policy of the government almost drove him to join the proposal to set up a government in exile with Ishak $\mathrm{Hj}$. Mohammad, Dato' Raja Abu Hanifah, and Aziz Ishak in 1965 (Saliha 1997). Before they could move to their destination in Pakistan, they were put under Internal Security Act (ISA) arrest on 18 January 1966 (Saliha 1997). Dr. Burhanuddin was granted a freedom a year later (1967) but could no longer participate in politics. The internal security act successfully drove the political career of Dr. Burhanuddin al-Helmy to an end. He passed away on October 10,1969 at the age of 58, just after the ban towards him has been lifted.

\section{His Thought}

In this section, the authors wish to elaborate among the prevalent thought or idealism of Burhanuddin al-Helmy which is summarized into four; 1) his views concerning Malay nationalism, 2) his dreams of achieving greater Malaya, 3) the status of Malay sultan, and 4) his call for reforms in the society.

\section{Malay Nationalism}

In justifying the nationalism that he was proposing, Dr. Burhanuddin first tried to affix it with the concept of 'asabiyyah with Islamic interpretation accompanying it. He stressed that his idea of Malay nationalism was not the narrow 'asabiyyah Jahiliyyah condemned by Prophet Muhammad (s.a.w.) (W. Mohd Azam 1997). His scope of nationalism struggle was wide and as stressed by him, to be in line with Ibn Khaldun's explanation of 'asabiyyah. 'asabiyyah literally referring to the narrow tribal feeling. He then goes further by saying that the call of the Prophet was from one nation to another nation and eventually be mould into international (W. Mohd Azam 1997). To him, 'asabiyyah is natural or an attitude that benefited human kind, as long as it did not led to a narrow tribalism. In al-Qur'an, Allah s.w.t. said that the purpose of Him creating different nation is for human being to get known each other and to benefit from that interaction. The nationalism or 'asabiyyah that he brings was still using the true banner of Islam in which using al-Qur'an as its guidance. He further called for all Muslims to take part in nationalism; nationalism for independence, humanity, and well being (W. Mohd Azam 1997).

Dr. Burhanuddin continued to elaborate that Islam looks at nationalism only as tools but not the sole aim. Nationalism should be mould and eventually become the symbol of unity of force, aiming for bigger and eternal ambition, just as Islam looks at worldly life as tools to reach the eternal life in hereafter (W. Mohd Azam 1997). The concept of love of nation was derived from the famous saying, Hubb al-watan min al-iman. To him, the call to Islam will not be complete without using the force of 'asabiyyah. On matter of hubb al-watan, he stated that its philosophy consists of four elements; Iman (soul), physical, races, and watan, none can functions without the others (Siddiq 2012). When a nation is being persecuted, the religion will also be suppressed. Stronger nation will guarantee the strength of religion being protected.

The seed for the idea of Greater Malaya was derived from this explanation; ranging from Islamic interpretation of 'asabiyyah, love of nation, to the unification of all Malays territories. It should be noted that although he came with all kinds of ideas and were labelled as radical Malay leader, never did he chose to gain independence by means of revolution. The concept of Greater Malaya was based on the love of nation belonging to all Malays. Its objective is to provide a special territory to the Malays so they will be respected and have the same status as the other races (W. Mohd Azam 1997). He objected that this motion was a kind of racism saying that all those countries intended to be in Greater Malaya were owned by the Malays. Unless the rights are returned to its owner, the struggle for justice and ownership will forever prevail. Due to the treatment of the colonizer, it was considered as threatening the watan of the Malays and he call

https://doi.org/10.24035/ijit.3.2013.008 
for a Jihad against all negative foreign influence. It was clear that the struggle against colonization could be carried in two stages; (1) individual and group stage, the struggle of religious leaders particularly the Tariqat Sufiyyah, and (2) the national stage.

It should also be noted here that Dr. Burhanuddin promoted the true concept of nationalism, denoting the holistic meaning of independence and sovereignty, whereby the culture and intellect orientation of a group of society only serves as the reflection of its national identity (Saliha 1997). His main theme is Malay Nationalism, Malay sovereignty and Greater Malaya (Siddiq 2012). One has to bear in mind that his concept of Malay nationalism is not racial-based and narrow. To him, those who opted to have loyalty to Malaya and struggles to realize its national aspiration, is regarded as abiding to the concept of Malay nationalism in its political sense (Saliha 1997). The word "Malay" is only a political terminology which gives identity to its citizens and as to respect its original inhabitants, the Malays. This is a sort of political assimilation to the non-Malays so that this country would have its distinct identity and reputation in the international world (Saliha 1997). Dr. Burhanuddin further motion that all nationals in Malaya be accorded as Malays, saying that the concept of Malay citizenship and its ideals about the Malay nationalism does not aim at creating conflicts and racial clash (Siddiq 2012).

\section{The Idea of Greater Malaya}

In the early stage of his political career, one of his famous ideologies was the unification with Indonesia, known as Greater Malaya. His interest in promoting the ideology of Greater Malaya was very clear during his leadership in PKMM, from 1946 to 1947 (Ramlah 1993). Starting from 30 November to 3 December 1945, Parti Kebangsaan Melayu (PKM) had succeeded in establishing a national congress, attended by members from all over branches of PKM. After four days, PKM had come out with four main resolutions (Kamarudin 1980): Malaya to be part of Indonesia; Sang Saka Merah Putih would be the official flag of Greater Malaya; Solemnly agreed to one union of Malaya, and; to establish good relation with the other races of Malaya.

Persatuan Kebangsaan Melayu Malaya was established as the result of this agreement, to carry out their political aspiration. Five months following the event, United Malays National Organization (UMNO) was formed under the leadership of Dato' Onn b. Ja'far. Earlier, his dream of achieving independence with Indonesia was made public during the meeting of KRIS Youth (Kesatuan Rakyat Indonesia Semenanjung) in 16 July 1945 (Ramlah 1993). Many people questioned his eagerness to have union with Indonesia. Greater Malaya to him is a political unification for all Malays in the Malay World. He always look at other countries (Singapore and Philippine) as forming a major political entity in international societies or better known as the Malay World. It was the world that has been segregated, divides, and ruled by the colonizers. The time has come for all members of the Malay world to unify and to return to the spirit of solidarity. Dr. Burhanuddin had widened the membership of Malaysia to include Indonesia and Philippine (alongside Singapore, Brunei, Sabah and Sarawak). The Parliament however, rejected this proposal, arguing that it would only cause tension between those territories (Saliha 1997). Defending his motion, Dr. Burhanudin argued that the union will deepen the harmonious relationship that has been there for a long time. One could see that his ideology of Greater Malaya or Indonesia was synonymous with his concept of Malay nationalism. He viewed that the union would bring greater solidarity for all sects of Malays or rumpun Melayu, where all Malays are being unified in one watan, having similar feeling of nationalism. When watan are strong, religion (Islam) would also be strong.

\section{The Status of the Sultan}

History had recorded that British colonization in Malaysia started with the personal interest of the much-respected Sultans. Starting from the year 1511, the fall of Malacca had brought many drawbacks to the Malayan Peninsula and also the Malay World. Foreign power continued to 
dominate this part of the world, coming one after the other. The first foreign power to dominate Malaya was the Portuguese, followed by the Dutch, and later British. The coming of British at first was as always, on basis of trade. But when local Sultans seek their help in managing their states and protecting their interest, the British motive was no longer on business. They had come for colonization. For a long time, it is the custom of the Malay on never to disobey the order of his sultan, be it good or the other way around. So it was the full control of sultan over his subjects that no one dared to stand up against the foreign intervention. The role of the sultans were not clear even in the Malay uprising against the British rules, such as the struggle of Dato' Bahaman in Pahang, Tok Janggut in Kelantan, Dol Said in Naning, and Haji Abdul Rahman in Terengganu. Their failure to predict the move and intention of the British proved to be catastrophic to the Malay world.

Although Dr. Burhanuddin continuously criticizes the weakness of the sultans in his writing and asking to limit their power, never did he suggests that their role or special status be abolished once and for all, or to end it by means of revolution. After the end of the First and Second World War, many Malays had realized the need to be free from the British rule. In his book Perjuangan Kita, Dr. Burhanuddin listed down several rhetorical questions to be considered by the Malay nationalists. Among it that stroke on the role of the sultans is; 1) determining the real Malay sultan deserving the obedience of the Malays as once practiced during the heyday of Malay's sultanate, 2) being disloyal to the sultan is contrary to the tradition passed from generation to generation, 3) the status of the sultan prior to the treaty with East India Company and the purpose of the treaty itself, 4) decreasing support of the people towards the sultan, and 5) the responsibilities of the sultans towards their subjects and states and, the realization of people towards their rights over their states and sultans (Burhanuddin 1946).

However, as his idea will limit the influence and interest of the Sultans, they never supported him. From their (the sultans) perspective, his movement is not aiming to safeguard their importance and the rights of the citizens, per se Malaya. On the other hand, this is one of the main agenda of UMNO (Ramlah 1993). When PKMM had withdrawn from the union with UMNO, the same question emerged once again. This time, it was expressed coherently. He seems skeptic with the effort of UMNO to restore the sultan as the head of Malay's state, and sole protector of Malays politics and custom, when they had again and again surrendered their power to the British (Kamarudin 1980). He also questioned the fate of the Malays, questioning that is it up to the sultan to safeguard the well being of the Malays or it is by the Malays themselves? (Kamarudin 1980). However, on the later stage, he had soften his stand towards the local sultan when he said that in line with promoting the Malay special position, the sovereignty of the Sultan should also be retained equally (Saliha 1997).

Following independence in 1957, the Malay sultans were installed as a constitutional monarch, meaning that they are bound by the constitution, negating the absolute control over the people. It is clear that the monarchy system in Malaysia were able to sustain until now although they did not receive mandate from the people (Abdul Aziz 2006). Malaysia is well known as practicing a parliamentary democracy. Although monarchy roles seem to be outdated, nevertheless, it helps to create stability which enables democracy to progress (Abdul Aziz 2006). It is agreed that immunity is given to the monarch on ground that they had surrendered their absolute control in the spirit of democracy, and at the same time, this immunity would allow them to execute their responsibilities without fear or favour of the government. In relation to the abolishment of the monarch legal immunity, the year 1993 witnessed an act of the executive and legislative in amending the federal constitution. This was during the premiership of Tun Mahathir Mohammad due to the allegation of abuse of power by the Sultan of Johor. The amendment in 1993 saw the existence of a new institution called as the Special Court meant for the monarch (Abdul Aziz 2006).

Due to the amendment, the absolute immunity once enjoyed by the monarch was now subject to the action of the said Special Court (Abdul Aziz 2006). Not only that, this amendment had shifted the authority to grant pardon from the Yang di-Pertuan Agong to the Council of Rulers should any offence committed by his families or by the other monarch. Previously, any 
criticisms towards the Malay rulers are subject to Sedition Act, the amendment in 1993 however had loosen this terms whereby only the Parliament or the State Legislative Assemblies can thrown criticism towards the Malay rulers including the Yang di-Pertuan Agong, so long as it did not lead to the abolishment of monarchy system (Abdul Aziz 2006). However, the amendment in 1993 only abolishes the immunity of the Yang di-Pertuan Agong on his personal capacity whereas he is still immune to the judicial process on his official capacity on ground that any court proceeding against them can only be carried after consultation with the Attorney General (Nadzan 2010). All in all, the amendment in 1993 did not entirely removed the immunity of the monarch whereby their sovereignty, authority and influence were still protected by the federal constitution (Nadzan 2010).

\section{The Need to Reform the Society}

Due the long span of colonization, the Malays have adapted many foreign influences, be it good or vice versa. In his writing, Dr. Burhanuddin urged the Malays not to adopt the Western culture entirely or to be fascinated by it (Kamarudin 1980). Instead, one should take only those that are beneficial for not everything introduced by the West are negative. To him, "science does not value" everything. The other side of science should be filled with spiritual dimension. He continues to say that with the advancement of knowledge and science, the means to control the weakness of human became even. The overall success of science could not escape the natural order of the world, but only to make use of the secret of the natural force and its regulation. The intellects on the other hand wanted to search for the best means to manipulate all races and human being. The eruption of the First and Second World War was a blow for both scientist and intellectual all over the world (Kamarudin 1980).

In his writing, Dr. Burhanuddin mentioned that he belonged to the Naqshibandiyya Tariqat. In line with it, he was also proposing reforms that should be done by all Sufi and their Tariqat. To him, the right and pure Tasawwuf did not cause any obstacle to modernization, but also providing good spirit and encouragement based on the nature of humanity (Burhanuddin 1971). Tasawwuf should be the true mould of modernization where he asserts that material development without the assistance of spiritual element is similar to creating a human body without its ruh, and spiritual development alone is the same as a ruh without its physical appearance (Burhanuddin 1971). Therefore, both aspects are interwoven and cannot function without the other. He was urging the members of Tariqat to take a new step that was in line with the new developed world. Islam is the pulse of new civilization and therefore it is the responsibility of everyone to form a Jama'ah to face the ever challenging world (Burhanuddin 1971).

Even when he is promoting a reform in Islamic mould and urged people to be cautious of the Western influence, this does not mean that he is a "racist" or ignoring the non-Muslims. It should be bear in mind that he had incorporated the idea of loyalty to Malaya by the non-Malays settled here. Although some politicians called him a racist, Dr. Burhanuddin proved to be noble than that. He continuously calls for all people to be good to each other, saying that al-Qur'an mentioned about the purpose of creating different nations. Islam looks at all the descendent of Adam as having their own rights, be they Muslims or not, but the best of all is those who are strong in their Iman (Saliha 1997).

As a conclusion, the ideas promoted by Dr. Burhanuddin al-Helmy could best describe him as the Malay nationalist. Although he is better known in the political arena, he also left few ideologies as his legacy. There were not many references in Malaysia regarding this influential figure, probably because people viewed him as the opposition or coming from the left wing. The idea of Greater Malaya emerged because of the close relation between Malays in this part of the world with Indonesia. Problems known today as illegal workers did not exist in those days. The unification of all Malays territories was his dream for he viewed the union will strengthen and popularized the image of all Malays after a long period of colonization. That union will prove 
that colonization did not lower the Malay self-esteem. They too can succeed just as other nation is.

Secondly, the influence received during his studies has very clear impact in his ideology. Ideas such as limiting the power of the Sultan might have come as a result of Middle East influence, as well as from his personal experience in India and Palestine. He closely observed that feudalism is a barrier between the ruler and the ruled.

Because of long span of colonization, Malaya was introduced to many kinds of foreign/western influence, be it good or vice versa. He urged the Malays on not to adopt all foreign culture without thinking of its later consequences. However, this does not make him a racist. This is clear in his book Falsafah Kebangsaan Melayu that it was the Malay customs to treat others, including foreigners in good manner, without questioning their intention is. Being good to others is certainly a virtue, but because of the Malay's good manner also that this part of the world was colonized one after the other. The British once said that the Malays are so backward and lazy that they couldn't invent or produce even a needle, a saying that was remembered by few Malays nowadays.

\section{References}

Abdul Aziz Bari. 2006. Majlis Raja-Raja: kedudukan dan peranan dalam Perlembagaan Malaysia. Kuala Lumpur: Dewan Bahasa dan Pustaka.

Burhanuddin al-Helmy. 1946. Perjuangan kita. Singapore: Persatuan Kebangsaan Melayu Malaya. 1971. Simposium tasawwuf dan tariqat. Pulau Pinang: The United Press.

Kamarudin Jaffar. 1980. Dr. Burhanuddin al-Helmy: politik Melayu dan Islam. Kuala Lumpur: Yayasan Anda.

Nadzan Haron \& Rozeman Abu Hassan. 2010. Malaysia melangkah ke hadapan. Selangor: Penerbitan Multimedia Sdn. Bhd.

Ramlah Adam. 1993. Dr. Burhanuddin al-Helmy: kajian mengenai kegiatannya dalam PKMM 1946-1948. Kuala Lumpur: Akademi Pengajian Melayu Universiti Malaya. . 1999. Sumbanganmu dikenang. Kuala Lumpur: Dewan Bahasa dan Pustaka.

Saliha Hj. Hasan. 1997. Dr. Burhanuddin al-Helmy. In: Abdullah Zakaria Ghazali \& Adnan Hj. Nawang (Eds). Biografi tokoh pilihan Malaysia. Kuala Lumpur: Penerbit Universiti Malaya.

Siddiq Fadzil. 2012. Pembinaan bangsa: kepelbagaian dalam bingkai kesatuan. Amanat Pimpinan Sempena Muktamar Nasional keenam Wadah Pencerdasan Umat Malaysia (WADAH). Selangor: Wadah Pencerdasan Umat Malaysia.

2012. Islam dan Melayu: martabat umat dan daulat rakyat. Kajang: Akademi Kajian Ketamadunan, Kolej Dar-al-Hikmah.

W. Mohd. Azam Mohd. Amin. 1997. Antara 'asabiyyah dan nasionalisme: menurut pandangan Dr. Burhanuddin al-Helmy. Kuala Lumpur: Kumpulan Penerbitan Baiduri. 